Article

\title{
Preparation of Amphiphilic Chitosan-Graphene Oxide-Cellulose Nanocrystalline Composite Hydrogels and Their Biocompatibility and Antibacterial Properties
}

\author{
Ming-Chien Yang ${ }^{1,+} \oplus$, Yi-Qun Tseng ${ }^{1,+}$, Kun-Ho Liu ${ }^{2}$, Yu-Wei Cheng ${ }^{3,4}$, Wan-Tzu Chen ${ }^{1}$, \\ Wei-Ting Chen ${ }^{3}$, Chia-Wei Hsiao ${ }^{3}$, Ming-Chi Yung ${ }^{5, *}$, Chuan-Chih Hsu ${ }^{5, *}$ and Ting-Yu Liu ${ }^{3, *} \mathbb{D}$ \\ 1 Department of Materials Science and Engineering, National Taiwan University of Science and Technology, \\ Taipei 10607, Taiwan \\ 2 Advanced Delivery Biotechnology Co., Ltd., Hsinchu 30325, Taiwan \\ Department of Materials Engineering, Ming Chi University of Technology, New Taipei City 24301, Taiwan \\ Institute of Polymer Science and Engineering, National Taiwan University, Taipei 10617, Taiwan \\ 5 Division of Cardiovascular Surgery, Department of Surgery, School of Medicine, College of Medicine, \\ Taipei Medical University Hospital, Taipei 11031, Taiwan \\ * Correspondence: mcyung52@hotmail.com (M.-C.Y.); cchsu1967@hotmail.com (C.-C.H.); \\ tyliu0322@gmail.com (T.-Y.L.) \\ + Contributed equally to this work.
}

Received: 30 June 2019; Accepted: 25 July 2019; Published: 29 July 2019

\begin{abstract}
Environmental-friendly nanocomposite hydrogels of carboxymethyl-hexanoyl chitosan $(\mathrm{CHC})$, graphene oxide $(\mathrm{GO})$ and cellulose nanocrystals (CNCs) were combined to produce a bio-hydrogel with great biocompatibility and antibacterial ability. The size of the GO nanosheets was about $200-500 \mathrm{~nm}$, and the CNCs had a length of 100-200 nm and a width of 10-20 nm, as shown by transmission electron microscopy (TEM). X-ray photoelectron spectroscopy (XPS) was utilized for the analysis of the oxygen functional groups of GO. The homogeneous dispersion of the $\mathrm{CHC} / \mathrm{GO} / \mathrm{CNC}$ nanocomposite hydrogel showed significantly higher water absorption capacity and water retention capability. In addition, inhibition of a variety of microorganisms (gram-negative and gram-positive bacteria and fungi) by the introduction of the $\mathrm{CHC} / \mathrm{GO} / \mathrm{CNC}$ nanocomposite hydrogel demonstrated that there is a great opportunity to use it in the bio-medical field, such as for plastic masks and wound dressings.
\end{abstract}

Keywords: amphiphatic chitosan; cellulose nanocrystals; graphene oxide; nanocomposite hydrogel; antibacterial ability

\section{Introduction}

In recent years, various moisture-trapping and thermosensitive polymers including chitosan (CS), hyaluronic acid (HA), gelatin and poly (ethylene oxide) copolymers have been developed and applied in a variety of fields. Among them, CS, fabricated by deacetylation of chitin, can provide a cationic polysaccharide, and is biocompatible and bio-degradable. Thus, CS plays an important role in many biological processes, such as tissue hydration, proteoglycan organization, and cell differentiation. Recently, CS was considered as an outstanding material for environmental protection [1] and a candidate for environmental and energy issues [2]. However, it is insoluble in aqueous solution, which restricts its biomedical application. Under neutral conditions, amphiphatic chitosan (carboxymethyl-hexanoyl chitosan, $\mathrm{CHC}$ ) has great water-absorption and water-retention capabilities [3]. $\mathrm{CHC}$, a water-soluble 
chitosan derivative, integrates the hexanoyl (hydrophobic) and carboxymethyl (hydrophilic) groups together. In addition, $\mathrm{CHC}$ possesses good biocompatibility, transparency and biodegradable properties, which offers huge potential for many applications. [4]

The highly crystalline, rod-like, cellulose nanocrystal (CNC) fibers are separated by acid hydrolysis from natural cellulose fibers [5]. There are many inherent features of CNCs, such as high surface area, nanoscale dimensions, high specific strength, low coefficient of thermal expansion, low density, and a strong Young's modulus [6]. Polysaccharide chains (CS) that include a hydroxyl can easily bond with $\mathrm{CNCs}$, due to the plentiful hydroxyl groups on the surface of CNCs $[7,8]$.

Chemically modified carbon materials, such as graphene or carbon nanotubes, have been investigated in many biomedical fields, due to their outstanding thermal, mechanical, and electrical properties $[9,10]$. The common method of exfoliating graphite flakes involves oxidizing agents to form hydrophilic nanosheets of graphene oxide (GO) [11,12], which can easily be dispersed in water. A series of reactive oxygen functional groups on the surface of GO gives it potential to self-assemble and inhibit bacterial growth. [13]

Thus, in this research, the nanocomposite hydrogel $(\mathrm{CHC} / \mathrm{GO} / \mathrm{CNC})$ was prepared by an uncomplicated solution casting method. The nanocomposite hydrogel was designed for use in bio-medical applications, such as plastic masks, wound dressings and tissue engineering [14,15]. We expected CNC to homogeneously disperse the GO nanosheets in water, in order to ensure great compatibility with the addition of the $\mathrm{CHC}$ polymer matrix. The features of the nanocomposite hydrogel were evaluated by transmission electron microscope (TEM), X-ray photoelectron spectroscopy (XPS), X-ray diffraction (XRD), Fourier transform infrared spectroscopy (FTIR), and Raman spectroscopy. Furthermore, biocompatibility and antibacterial capability was also investigated.

\section{Materials and Methods}

\subsection{Materials}

Chitosan (Mw 215,000 $\mathrm{g} \cdot \mathrm{mol}^{-1}$, deacetylation degree 85-90\%) and graphite flakes (cat\#332461, $\sim 150 \mu \mathrm{m}$ flakes) were supplied from Aldrich-Sigma. Through milling with a 60-mesh screen, the cellulose filter was obtained (Thomas-Wiley Laboratory Mill model 4, Thomas Scientific, Logan Township, NJ, USA).

\subsection{Synthesis of $\mathrm{CHC}$}

The skeletal structure of $\mathrm{CHC}$ was used to form a hyaluronic acid-like structure, which was synthesized by selecting N, O-carboxymethyl chitosan (NOCC) as a starting precursor [3]. NOCC with high carboxymethyl substitutions (2 g) was dissolved in distilled (DI) water (50 mL) and stirred for $24 \mathrm{~h}$. Subsequently, the resulting solution was added to the methanol $(50 \mathrm{~mL})$, followed by addition of $0.5 \mathrm{M}$ hexanoyl anhydride for a reaction time of $12 \mathrm{~h}$ to form $\mathrm{CHC}$ with a high hexanoyl substitution. Finally, the resulting solution was purified by dialysis with ethanol solution $(25 \%, v / v)$ for $24 \mathrm{~h}$. The soluble chitosan derivatives were obtained in ethanol/water (volume ratio $=3: 2$ ) as $\mathrm{CHC}$.

\subsection{Synthesis of $G O$}

Graphene oxide (GO) was fabricated from high-purity natural graphite flakes by the modified Hummers method [16], which is a relatively safe and rapid method. First, $69 \mathrm{~mL}$ of concentrated $\mathrm{H}_{2} \mathrm{SO}_{4}$ was slowly added to a mixture of $\mathrm{NaNO}_{3}(1.5 \mathrm{~g})$ and graphite flakes $(3.0 \mathrm{~g})$ and cooled to $0{ }^{\circ} \mathrm{C}$. We ensured the above solution remained below $20^{\circ} \mathrm{C}$ while $9.0 \mathrm{~g}$ of $\mathrm{KMnO}_{4}$ was added slowly in portions. Following that, the reaction solution was stirred at $35^{\circ} \mathrm{C}$ for $30 \mathrm{~min}$. An additional $3 \mathrm{~mL}$ of $\mathrm{H}_{2} \mathrm{O}_{2}(30 \%)$ and $420 \mathrm{~mL}$ of water were added, producing an exothermic reaction. Under air cooling, the resulting mixture was purified (including multiple washings, filtration, centrifugation and cooling vacuum drying) to produce the solid GO powders. 


\subsection{Synthesis of $\mathrm{CNC}$}

The synthesis of CNC fibers was separated by acid hydrolysis from natural cellulose fibers. Hydrolysis was carried out using $64 \%(w / w) \mathrm{H}_{2} \mathrm{SO}_{4}$ at $45^{\circ} \mathrm{C}$ for $120 \mathrm{~min}$ and diluted 10-fold with cold $\left(4^{\circ} \mathrm{C}\right)$ water to terminate the reaction. The suspension was washed and dialyzed until a neutral $\mathrm{pH}$ to obtain the resultant $\mathrm{CNC}$ fibers.

\subsection{Preparation of Nanocomposite Hydrogels (CHC/GO/CNC)}

The CHC was dissolved in an aqueous solution by using a magnetic stirrer at $200 \mathrm{r} / \mathrm{min}$ for $2 \mathrm{~h}$ to obtain the concentration of $2.5 \mathrm{wt} \%$ of $\mathrm{CHC}$ solution. The CNC/GO suspension with the concentration ratio of 12:0.5 $\mathrm{wt} \%$ was first diluted and ultrasonicated for $5 \mathrm{~min}$. Following that, the above suspension was added to a solution of $\mathrm{CHC}(0.05-2 \mathrm{wt} \%)$, and then stirred for $30 \mathrm{~min}$. The resulting mixture was degassed in a vacuum oven for $3 \mathrm{~h}$. Subsequently, the $\mathrm{CHC} / \mathrm{GO} / \mathrm{CNC}$ solutions were heated to $50^{\circ} \mathrm{C}$ in the hydrophobic glass plates to remove the solvents. In this way, the $\mathrm{CHC} / \mathrm{GO} / \mathrm{CNC}$ nanocomposite hydrogel was produced. The mean thickness of the nanocomposite hydrogel was about $0.1 \mathrm{~mm}$.

\subsection{Characterization}

FTIR spectra (Bruker Corporation, VX70) were measured from 400 to $3800 \mathrm{~cm}^{-1}$ by the $\mathrm{KBr}$ pressing plate method. The morphological characterization was examined by a scanning electron microscope (SEM, JSM-6700F, JEOL, Tokyo, Japan) and transmission electron microscope (TEM) (JOEL JEM-2100) with an accelerating voltage of $120 \mathrm{kV}$. The crystalline phases present in the samples were measured by X-ray diffraction (XRD) by using PANalytical-X'Pert PRO MPD with a Cu K $\alpha$ X-ray source $(\lambda=1.5405 \AA$ ). The XPS spectra (wide scans and C 1s, O 1s) were performed by using VG Scientific ESCALAB Spectrometer with $\mathrm{Mg} \mathrm{K} \alpha$ radiation $(\lambda=1253.6 \mathrm{eV})$. The sedimentation rate of $\mathrm{CHC} / \mathrm{GO} / \mathrm{CNC}$ suspensions were evaluated by the LUMiSizer ${ }^{\circledR}$, which is an analytical centrifuge that instantaneously measures the extinction of the transmitted light across the entire length of your sample using STEP-Technology (space- and time-resolved extinction profiles, ISO 13318-2). The water-absorption capability $\left(\mathrm{W}_{\mathrm{c}}\right)$ was calculated by the percentage of weight change of the dry sample (pressing disk, $1 \mathrm{~cm}$ of diameter $\times 1 \mathrm{~cm}$ of height) [17]:

$$
\mathrm{W}_{\mathrm{c}}(\%)=\left(\mathrm{W}_{\mathrm{w}}-\mathrm{W}_{\mathrm{d}}\right) / \mathrm{W}_{\mathrm{d}} \times 100 \%
$$

where $\mathrm{W}_{\mathrm{d}}$ and $\mathrm{W}_{\mathrm{w}}$ are the weights of the sample before and after the water-absorption test $(\mathrm{pH}=7)$. The moisture absorption sample $\left(\mathrm{W}_{\mathrm{w}}\right)$ was exposed to the same environment $\left(\mathrm{T}=24^{\circ} \mathrm{C}, \mathrm{RH}=50 \%\right)$ and immersed in DI-water for $1 \mathrm{~h}$. In the calculation method of $\mathrm{W}_{\mathrm{w}}$, the excess water was removed by using a filter.

\subsection{Biocompatibility and Antibacterial Activity}

The cytotoxicity was evaluated with $3 \mathrm{~T} 3$ fibroblasts. The culture medium was $1 \%$ penicillin antibiotic (PNC) and DMEM including 10\% fetal bovine serum (FBS). The CHC/GO/CNC nanocomposite hydrogels $(1 \mathrm{~cm} \times 1 \mathrm{~cm})$ were autoclaved before placing them in the wells of a 12-well plate. In each well, $1 \mathrm{~mL}$ of the medium containing $10^{5}$ cells was added. Then the plates were cultured in a humidified $37{ }^{\circ} \mathrm{C}, 5 \% \mathrm{CO}_{2}$ incubator. On the $1 \mathrm{st}, 3 \mathrm{rd}$, and 5 th days, the cell growth was determined by the thiazolyl blue tetrazolium bromide (MTT) assay. Briefly, $20 \mu \mathrm{L}$ of reagent were added into each well and incubated for $4 \mathrm{~h}$ at $37^{\circ} \mathrm{C}$. Then, dimethyl sulfoxide (DMSO) was mixed with the medium to dissolve the purple product. Finally, the absorbance at $570 \mathrm{~nm}$ was registered.

In brief, the frozen preserved stock of bacteria was thawed at room temperature. After that, $0.1 \mathrm{~mL}$ of preserved stock was pipetted and streaked onto a quadrant on a nutrient agar plate. The nutrient agar was composed of $10 \mathrm{~g}$ DifcoTM LB Broth mixed with $6 \mathrm{~g}$ agar bacteriological LP0011 powder and diluted with DI water $(400 \mathrm{~mL})$, and the formation of colonies was cultured at $37^{\circ} \mathrm{C}$ for $18-24 \mathrm{~h}$. Subsequently, a single colony was carefully scraped with a loop and swabbed onto a $15^{\circ}$-slant medium 
(nutrient agar) and then incubated at $37^{\circ} \mathrm{C}$ for $18-24 \mathrm{~h}$. Following that, $1 \mathrm{wt} \%$ of $\mathrm{NaCl}$ solution $(2 \mathrm{~mL})$ was added to the slant medium and stirred with a vortex mixer for $30 \mathrm{~s}$. Then, $1 \mathrm{~mL}$ of mixture solution was added into $9 \mathrm{~mL}$ of nutrient broth (5 g DifcoTM LB Broth, Miller powder/200 mL DI-water) and mixed with a vortex mixer, then $1 \mathrm{~mL}$ of the first nutrient broth solution was mixed into $9 \mathrm{~mL}$ of new nutrient broth. This process was repeated four times in a row. An aliquot of $1 \mathrm{~mL}$ of nutrient broth containing bacteria $\left(1 \times 10^{5} \mathrm{CFU} / \mathrm{mL}\right)$ was added to a flask containing $1 \mathrm{~mL}$ of $\mathrm{CHC} / \mathrm{GO} / \mathrm{CNC}$ nanocomposite hydrogel. This was followed by shaking by a rotary shaker at $250 \mathrm{rpm}$ for $20 \mathrm{~min}$. After $18 \mathrm{~h}$ of incubation, the number of surviving bacteria was counted.

\section{Results}

\subsection{Characteristic of GO and CNC}

The individual nanosheets were $200-500 \mathrm{~nm}$ in diameter and most likely consisted of a few layers, as shown in Figure 1a. The diffraction patterns indicated a roughly hexagonal crystallinity (Figure 1b). Furthermore, the length and the width of the CNCs were about 100-200 nm and 10-20 nm, respectively. The XRD spectra (Figure 2) showed that the $2 \theta$ of the graphite flakes $\left(26.4^{\circ}\right)$ shifted to $9.6^{\circ}$ of the GO nanosheets [18-20]. This indicates that the d spacing of the GO nanosheets increased (1.73A of the graphite flakes expanded to $4.62 \AA$ of the GO nanosheets) after the oxidation and intercalation process of the graphene nanosheets. In addition, the XPS spectra support the conclusion that GO was oxidized (Figure 3). The C1s of the XPS spectra (Figure 3a) were drawn by curvefitting each spectrum to four peaks, corresponding to the functional groups: carboxylates $(\mathrm{O}-\mathrm{C}=\mathrm{O}, 289.0 \mathrm{eV})$, carbonyl $(\mathrm{C}=\mathrm{O}, 287.8 \mathrm{eV})$, epoxy/hydroxyls $(\mathrm{C}-\mathrm{O}, 286.2 \mathrm{eV})$, and carbon sp ${ }^{2}(\mathrm{C}=\mathrm{C}, 284.8 \mathrm{eV})$ [21-23]. The O1s of the XPS spectra (Figure $3 \mathrm{~b}$ ) displayed a peak in the range of $530-537 \mathrm{eV}$, showing that the oxidized functional group was formed at the GO nanosheets.
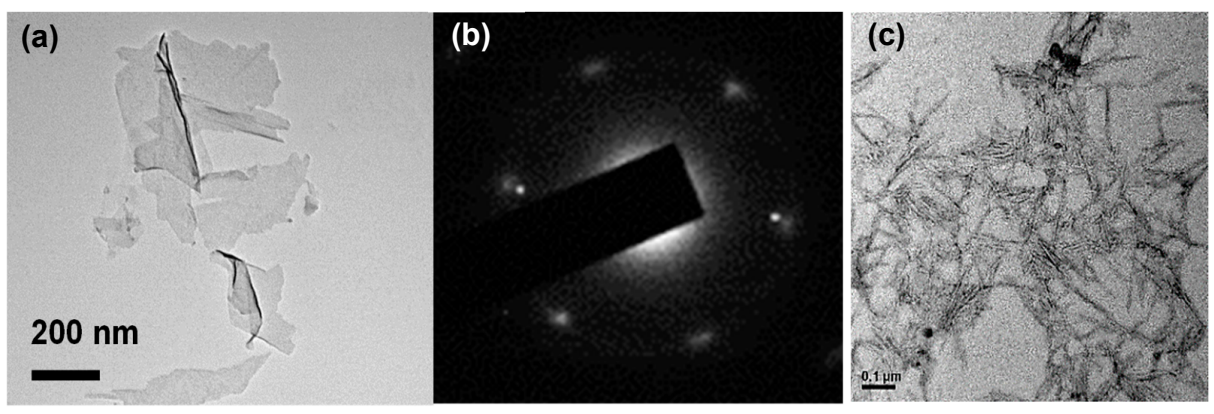

Figure 1. (a) TEM images and (b) selected area electron diffraction (SAED) patterns corresponded to graphene oxide (GO) nanosheets; (c) TEM image of a cellulose nanocrystalline (CNC).

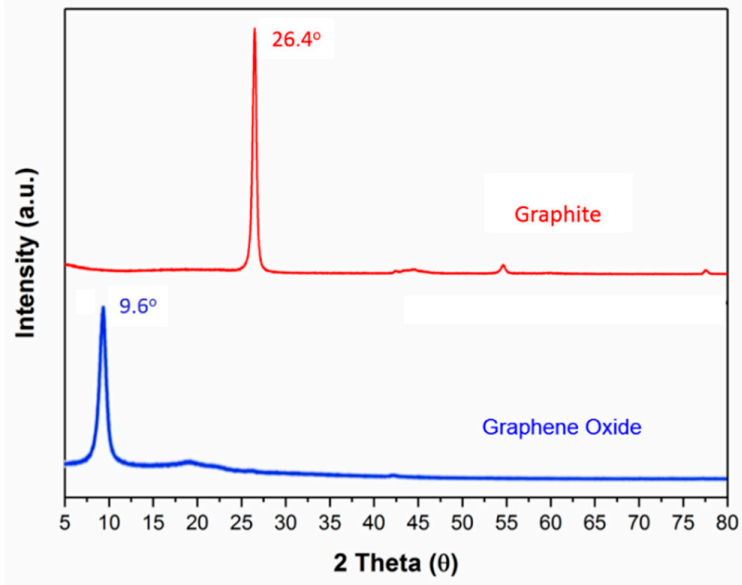

Figure 2. XRD spectra of graphite flakes and GO nanosheets. 

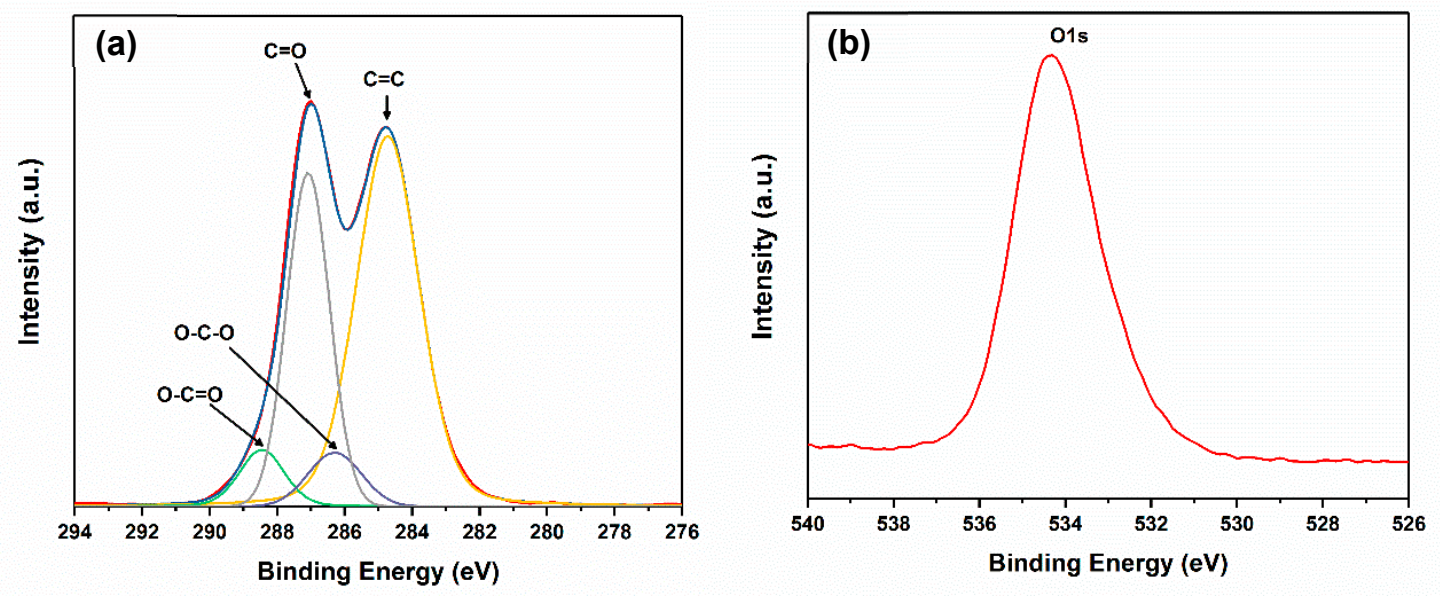

Figure 3. (a) C1s and (b) O1s XPS spectra of GO nanosheets.

The colloidal suspensions of the CNC exhibited a nematic liquid crystalline alignment after the acid hydrolysis conditions were optimized [24]. The XRD spectra (Figure 4) showed that the crystallization of the pristine cellulose at $2 \theta=15.9^{\circ}, 22.4^{\circ}$ and $34.6^{\circ}$. However, the half-height width at $2 \theta=22.4^{\circ}$ in the pristine cellulose decreased from $1.97^{\circ}$ to $1.37^{\circ}$ after the cellulose was hydrolyzed by sulfuric acid (CNC). This indicated that the pristine cellulose fibers were decomposed to nanoscale fibers, but still retained the crystallization. The CNC displayed six crystalline peaks at $2 \theta=14.9^{\circ}, 16.3^{\circ}$, $22.4^{\circ}, 30.8^{\circ}, 38.4^{\circ}$, and $44.6^{\circ}$, showing that it had a higher crystallization than in pristine cellulose.

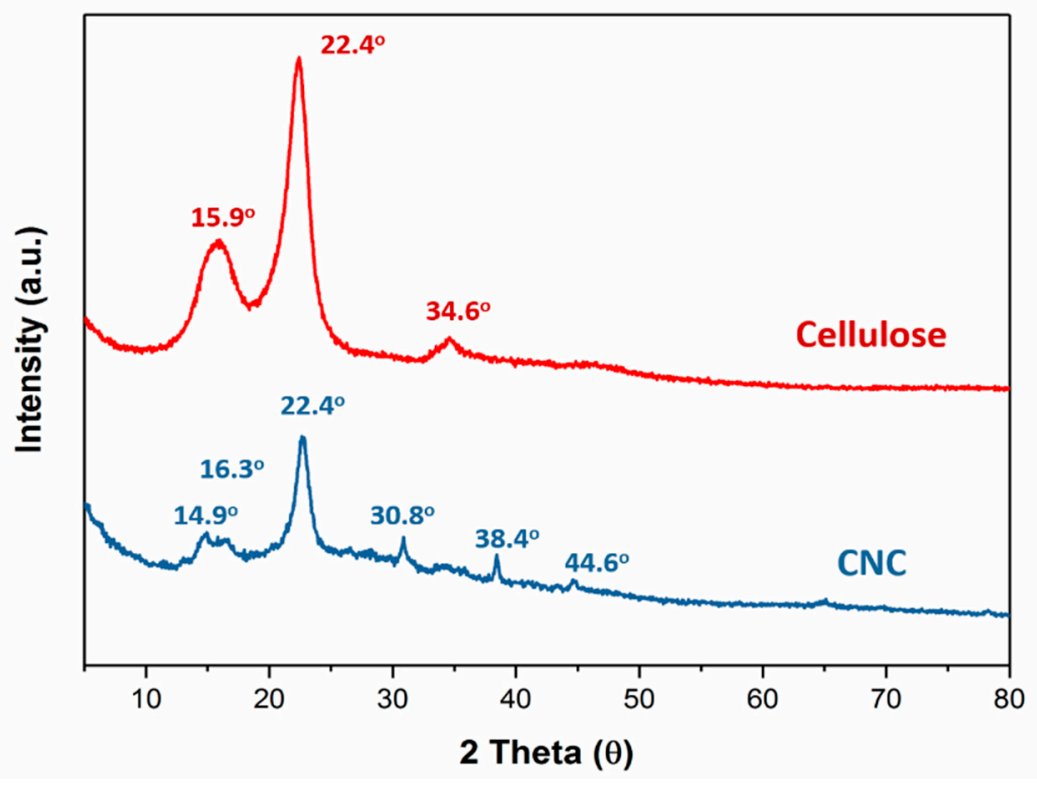

Figure 4. XRD patterns of pristine cellulose, $\mathrm{CHC}$, GO and CHC/GO/CNC.

Furthermore, from FTIR spectra (Figure 5), the splitting peak at $1110 \mathrm{~cm}^{-1}$ was found in the $\mathrm{CNC} / \mathrm{GO}$ nanocomposites, showing the interaction between $\mathrm{CNC}(-\mathrm{OH})$ and $\mathrm{GO}(-\mathrm{COOH})$. Further, the characteristic functional groups of $\mathrm{O}-\mathrm{H}$ and $\mathrm{C}-\mathrm{O}-\mathrm{C}$ still existed after the cellulose was hydrolyzed by sulfuric acid $(\mathrm{CNC})$. 


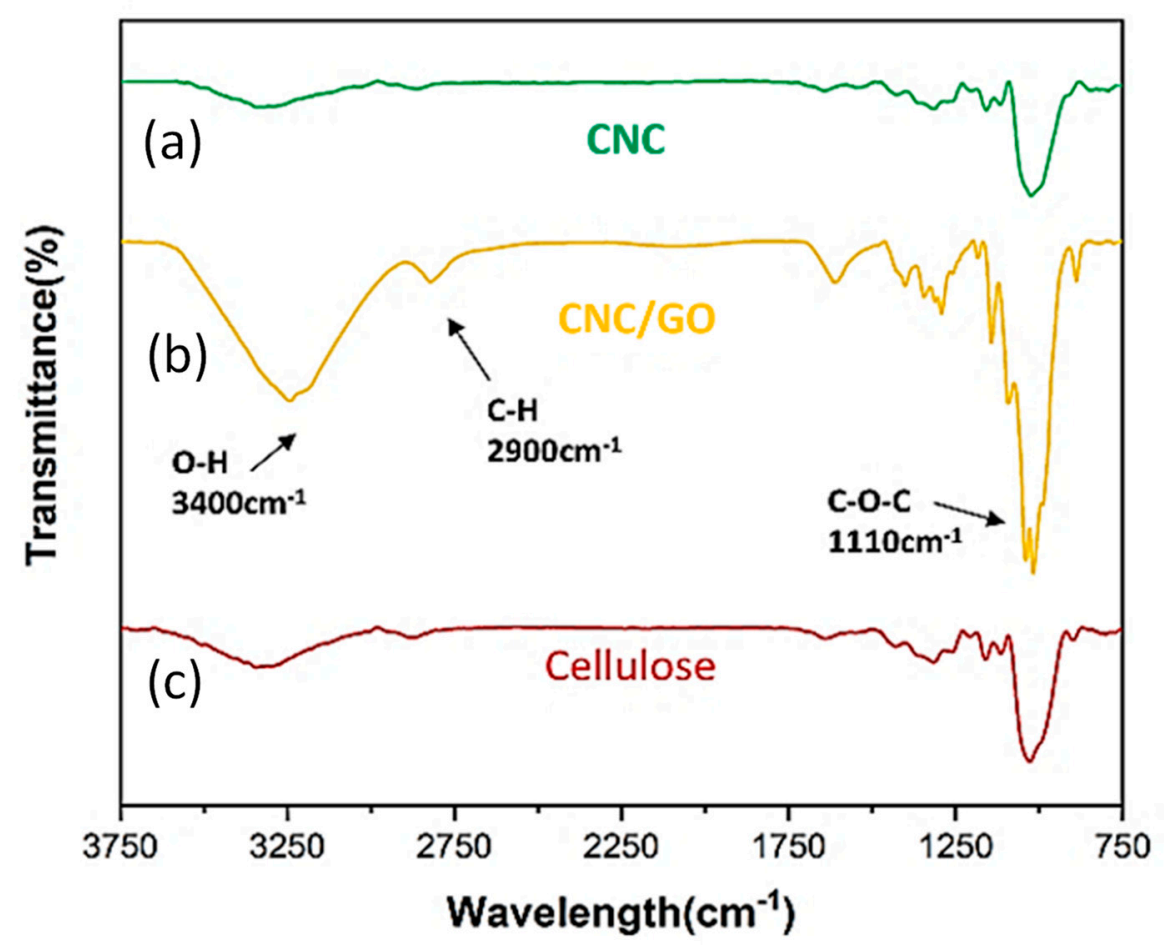

Figure 5. FTIR spectra of $\mathrm{CNC}, \mathrm{CNC} / \mathrm{GO}$ and pristine cellulose.

\subsection{Characteristic of CHC/GO/CNC Nanocomposite Hydrogels}

\subsubsection{Sedimentation Rate and Water Retention Analysis of CHC/GO/CNC Nanocomposite Hydrogels}

From the results of the Lumisizer ${ }^{\circledR}$ test (Figure 6) of the $\mathrm{CHC} / \mathrm{GO} / \mathrm{CNC}$ nanocomposite suspensions, we found that GO/DI-water (Figure 6a) was not well dispersed in water, and the sedimentation rate was $10.31 \mathrm{~mm} / \mathrm{h}$, which was the fastest settlement among the five samples. After addition of $\mathrm{CNC}$, the sedimentation rate of $\mathrm{GO} / \mathrm{CNC}$ decreased to $0.9 \mathrm{~mm} / \mathrm{h}$ (Figure $6 \mathrm{~b}$ ), showing significant improvement (the sedimentation rate decreased 11.5 times). Furthermore, the sedimentation rate of CHC/GO/CNC solutions at $0.05 \mathrm{wt} \%, 0.1 \mathrm{wt} \%$, and $0.2 \mathrm{wt} \%$ of $\mathrm{CHC}$ addition decreased to $0.66,0.2$, and $0.49 \mathrm{~mm} / \mathrm{h}$, respectively (Figure $6 \mathrm{c}$ ). With the addition of $\mathrm{CHC}$, the hydrogel viscosity rose and thus the sedimentation rate became slower. The optimal addition concentration of $\mathrm{CHC}$ was $0.1 \mathrm{wt} \%$ (Figure $6 \mathrm{~d}$ ), which gave the slowest sedimentation rate $(0.2 \mathrm{~mm} / \mathrm{h})$. However, the amount of CHC used was up to $0.2 \mathrm{wt} \%$ because as the viscosity became too high, the suspension property decreased (the sedimentation rate was $0.49 \mathrm{~mm} / \mathrm{h}$, Figure 6e).

From the results of the water retention analysis (Figure 7), the water absorption (\%) of the $\mathrm{CHC} / \mathrm{GO} / \mathrm{CNC}$ composite hydrogel ( $94 \%)$ was higher than chitosan and hyaluronic acid (HA) after $48 \mathrm{~h}$ incubation with $90 \%$ relative humidity (Figure $7 \mathrm{a}$ ). Further, the water absorption of the $\mathrm{CHC} / \mathrm{GO} / \mathrm{CNC}$ composite hydrogel was about $65 \%$ at $23 \%$ relative humidity (Figure $7 \mathrm{~b}$ ), and the water retention capacity was significantly higher than that of CS and HA at both humidity. This proves that the $\mathrm{CHC} / \mathrm{GO} / \mathrm{CNC}$ nano-network structure formed by the composite hydrogel exhibits a good water retention effect. Hence, the nano-fillers $(\mathrm{GO} / \mathrm{CNC})$ might play an important role in crosslinking the network structure of the nanocomposite hydrogel. In addition, the statistical analysis (Student's $t$-test) showed a significant difference $(p<0.05)$ between the two observed groups (chitosan with HA and $\mathrm{CHC} / \mathrm{GO} / \mathrm{CNC}$ ) at the relative humidity of $90 \%$ (Figure $7 \mathrm{a}$ ) and $23 \%$ (Figure $7 \mathrm{~b}$ ). 

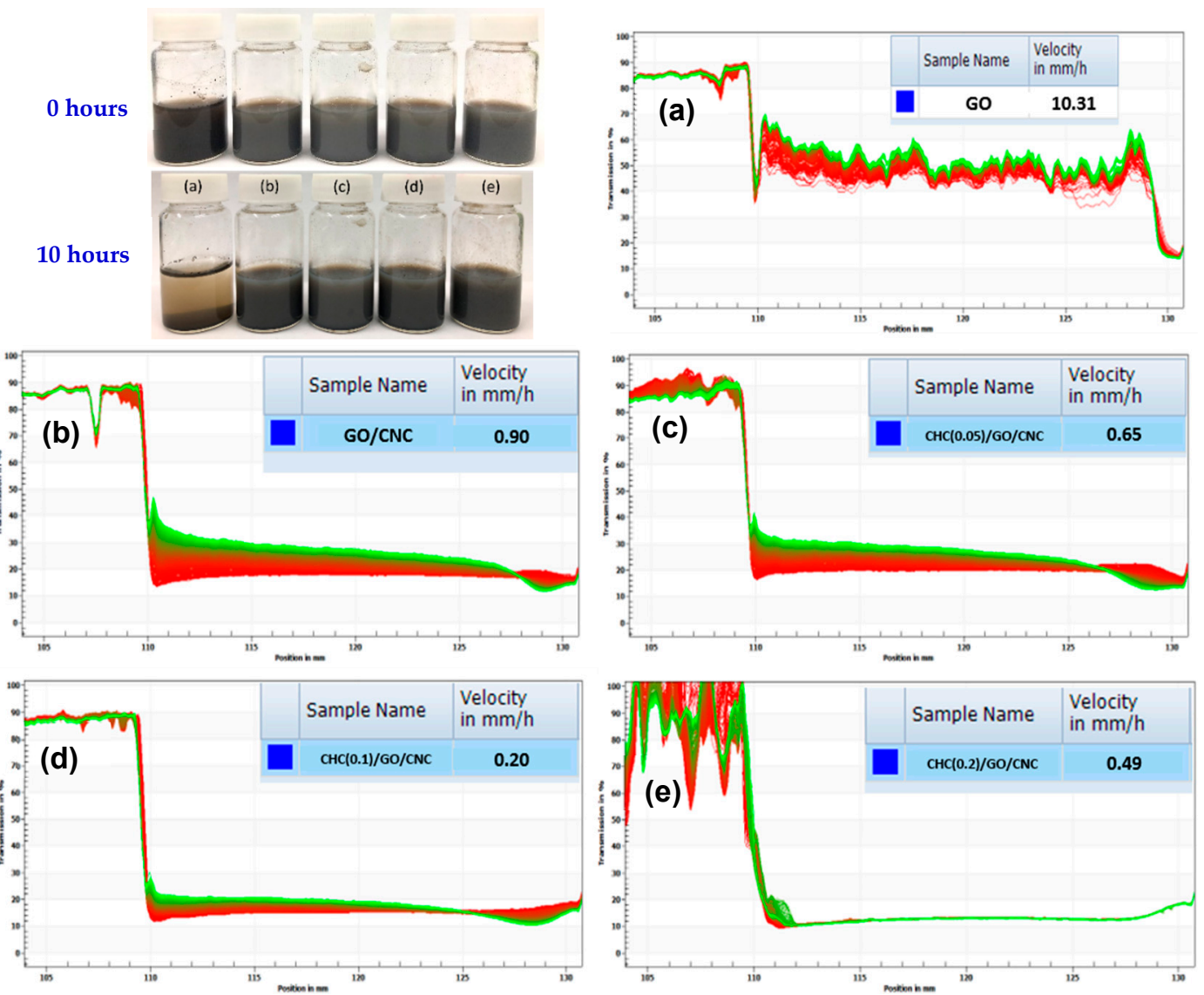

Figure 6. The sedimentation test at the initial state and after $10 \mathrm{~h}$ incubation in the water solution; and the Lumisizer ${ }^{\circledR}$ test (the sedimentation rate) of (a) GO; (b) GO/CNC, and the CHC/GO/CNC nanocomposite suspension with the different $\mathrm{CHC}$ concentrations of (c) $0.05 \mathrm{wt} \%$; (d) $0.1 \mathrm{wt} \%$; and (e) $0.2 \mathrm{wt} \%$.
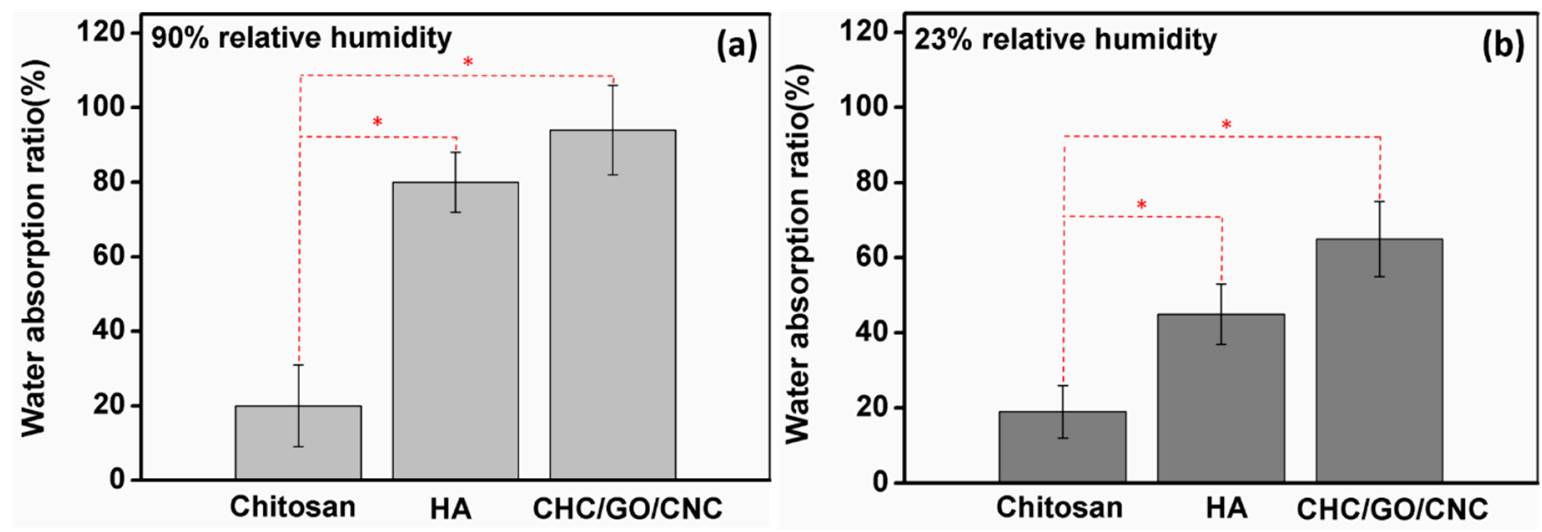

Figure 7. Water absorption ability of pristine chitosan (CS), hyaluronic acid (HA), and the nanocomposite hydrogel (CHC/GO/CNC) at the relative humidity of (a) $90 \%$ and (b) $23 \%$. * The statistical analysis (Student's $t$-test) showed a significant difference $(p<0.05)$ between the two observed groups (chitosan with $\mathrm{HA}$ and $\mathrm{CHC} / \mathrm{GO} / \mathrm{CNC}$, respectively) at the relative humidity of (a) $90 \%$ and (b) $23 \%$.

\subsubsection{Biocompatibility and Antibacterial Properties of the CHC/GO/CNC Nanocomposite Hydrogel}

From the results of the $3 \mathrm{~T} 3$ fibroblast survival assay (Figure 8), it was found that $5 \%$ DMSO addition (positive control) showed high cytotoxicity against 3T3 fibroblasts. However, it showed great biocompatibility in the sample of GO/CNC (without CHC). When the $\mathrm{CHC}$ addition was $0.05-0.1 \mathrm{wt} \%$, 
the cell viability (\%) was higher than the negative control (100\%), which can increase the growth of 3 T3 fibroblasts up to $10-20 \%$. When the concentration was higher than $0.5-2 \mathrm{wt} \%$, the cell viability dropped slightly to $98-100 \%$, but it still showed no cytotoxicity to $3 \mathrm{~T} 3$ fibroblasts.

In addition, according to the JIS Z2801: 2010 antibacterial quantitative analysis method, the bacteriostatic effects of $\mathrm{CHC} / \mathrm{GO} / \mathrm{CNC}$ nanocomposite hydrogels to various microorganisms (Escherichia coli, Staphylococcus aureus, Candida albicans) are shown in Table 1. The CHC/GO/CNC nanocomposite ( $2 \mathrm{wt} \%$ of $\mathrm{CHC}$ ) inhibits a variety of microorganisms, of which gram-negative bacteria (Escherichia coli) are more easily inhibited than other microorganisms, presumably because the surface of the $\mathrm{CHC}$ has a positive charge from its zeta potential and is in contact with the negatively charged cell wall of microorganisms. However, the negative charge of $\mathrm{GO} / \mathrm{CNC}$ addition is beneficial to the inhibition of gram-positive bacteria (Staphylococcus aureus). The bacteriostatic ratio (\%) of CHC/GO/CNC nanocomposite hydrogels is about $97.5 \%$, which is slightly lower than that for gram-negative bacteria (Escherichia coli $>99.9 \%$ ). Furthermore, because the 2D-materials of GO nanosheets are like a knife, it is easy to slice the cell wall of the fungus (Candida albicans). The bacteriostatic ratio (\%) of CHC/GO/CNC hydrogels for fungus is about $94.1 \%$, which can inhibit fungal growth. This interaction causes leakage of protein and other cellular components, which in turn causes the cell membrane to rupture and the microbes die.

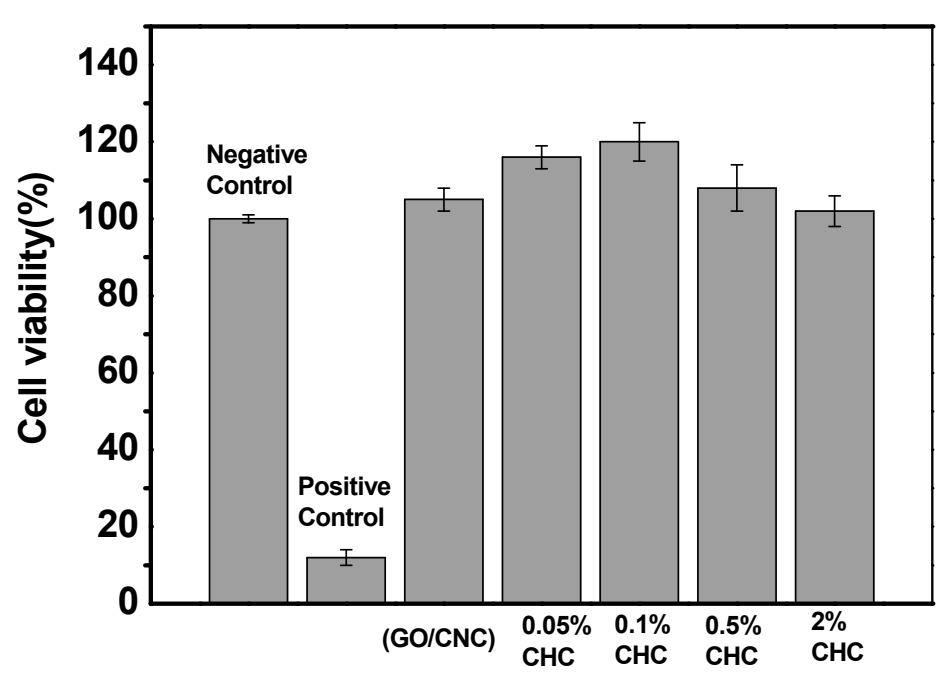

Figure 8. Cell proliferation of $\mathrm{L} 929$ cell with negative control and the $\mathrm{CHC} / \mathrm{GO} / \mathrm{CNC}$ nanocomposite hydrogel with the various $\mathrm{CHC}$ concentrations of $0.05,0.1,0.5$, and $2 \mathrm{wt} \%$ (negative control: DMEM + $10 \%$ FCS; positive control: DMEM + 10\% FCS + 5\% DMSO).

Table 1. Antibacterial activity of $\mathrm{CHC} / \mathrm{GO} / \mathrm{CNC}$ nanocomposite hydrogels.

\begin{tabular}{ccc}
\hline Microorganism & Type & Bacteriostatic Ratio (\%) (Ratio of MBC to MIC) \\
\hline Escherichia coli & gram-negative & $>99.99$ \\
Staphylococcus aureus & gram-positive & 97.5 \\
Candida albicans & fungus & 94.1 \\
\hline
\end{tabular}

\section{Conclusions}

In this study, the $\mathrm{CHC} / \mathrm{GO} / \mathrm{CNC}$ nanocomposite hydrogel displays great antibacterial activity, achieved by incorporating $2 \mathrm{wt} \%$ of the amphiphilic modified chitosan $(\mathrm{CHC})$ to biodegradable $\mathrm{CNC}$ and 2D materials (GO). Due to the homogeneous dispersion of $\mathrm{CHC} / \mathrm{GO} / \mathrm{CNC}$, it is not easy to sediment. The well suspension can persist for over 6 months. Furthermore, we proved that the obtained $\mathrm{CHC} / \mathrm{GO} / \mathrm{CNC}$ nanocomposites display great biocompatibility by the MTT tests, especially at the $0.1 \mathrm{wt} \% \mathrm{CHC}$ addition. To sum up, these advantages of $\mathrm{CHC} / \mathrm{GO} / \mathrm{CNC}$ nanocomposite hydrogels 
gives them a wide potential for use in commercial plastics/wound dressings; and promotes their use as a biomedical and environmental-friendly material.

Author Contributions: T.Y.L. and M.-C.Y. (Ming-Chien Yang) were supervisors of the research and revised the final manuscripts. Y.-Q.T., K.-H.L., and Y.-W.C. performed the synthesis of CNC, GO, and CHC. W.-T.C. (Wan-Tzu Chen), W.-T.C. (Wei-Ting Chen), and C.-W.H. performed the experiments of TEM, XRD, FTIR and XPS analysis. M.-C.Y. (Ming-Chi Yung) performed biological tests. C.-C.H. supervised the biological and antibacterial experiments and drafted the biological part of the manuscript.

Funding: This research and the APC was funded by the Ministry of Science and Technology, Taiwan (MOST 108-2218-E-002-010; MOST 107-2622-8-131-003; MOST 108-2622-E-131-002-CC3), and the industrial development bureau, Ministry of Economic Affairs of Taiwan (E10700010006-059, Conventional Industry Technology Development Plan).

Acknowledgments: We are grateful to the staff of Technology Commons, College of Life Science, Nation Taiwan University (NTU) for help with transmission electron microscopy (TEM), and facilities support by Wei-Bor Tsai and Ying-Chih Liao from the Department of Chemical Engineering, NTU.

Conflicts of Interest: The authors declare no conflicts of interest.

\section{References}

1. Liu, L.; Wang, B.; Gao, Y.; Bai, T.-C. Chitosan fibers enhanced gellan gum hydrogels with superior mechanical properties and water-holding capacity. Carbohyd. Polym. 2013, 97, 152-158. [CrossRef] [PubMed]

2. Chen, $\mathrm{Y}$.; $\mathrm{Hu}$, J.; Wang, J. Kinetics and thermodynamics of $\mathrm{Cu}$ (II) biosorption on to a novel magnetic chitosan composite bead. Environ. Technol. 2012, 33, 2345-2351. [CrossRef] [PubMed]

3. Liu, T.Y.; Chen, S.Y.; Lin, Y.L.; Liu, D.M. Synthesis and characterization of amphiphatic carboxymethyl-hexanoyl chitosan hydrogel: Water-retention ability and drug encapsulation. Langmuir 2006, 22, 9740-9745. [CrossRef] [PubMed]

4. El-banna, F.S.; Mahfouz, M.E.; Leporatti, S.; El-Kemary, M.; Hanafy, N.A.N. Chitosan as a Natural Copolymer with Unique Properties for the Development of Hydrogels. Appl. Sci. 2019, 9, 2193. [CrossRef]

5. Habibi, Y.; Lucia, L.A.; Rojas, O.J. Cellulose Nanocrystals: Chemistry, Self-Assembly, and Applications. Chem. Rev. 2010, 110, 3479-3500. [CrossRef] [PubMed]

6. Zheng, W.-L.; Hu, W.-L.; Chen, S.-Y.; Zheng, Y.; Zhou, B.-H.; Wang, H.P. High photocatalytic properties of zinc oxide nanoparticles with amidoximated bacterial cellulose nanofibers as templates. Chin. J. Polym. Sci. 2014, 32, 169-176. [CrossRef]

7. $\mathrm{Hu}, \mathrm{X}$.; $\mathrm{Xu}, \mathrm{C} . ; \mathrm{Gao}$ J.; Yang, G.; Geng, C.; Chen, F.; Fu, Q. Toward environment-friendly composites of poly(propylene carbonate) reinforced with cellulose nanocrystals. Compos. Sci. Technol. 2013, 78, 63-68. [CrossRef]

8. Yang, Q.; Fukuzumi, H.; Saito, T.; Isogai, A.; Zhang, L. Transparent cellulose films with high gas barrier properties fabricated from aqueous alkali/urea solutions. Biomacromolecules 2011, 12, 2766-2771. [CrossRef]

9. Park, S.; Ruoff, R.S. Chemical methods for the production of graphenes. Nat. Nanotechnol. 2009, 4, 217-224. [CrossRef]

10. Wissler, M.J. Graphite and carbon powders for electrochemical applications. J. Power Sources 2006, 156, 142-150. [CrossRef]

11. Higginbotham, A.L.; Lomeda, J.R.; Morgan, A.B.; Tour, J.M. Graphite oxide flame-retardant polymer nanocomposites. Appl. Mater. Interfaces 2009, 1, 2256-2261. [CrossRef] [PubMed]

12. Dreyer, D.R.; Park, S.; Bielawski, C.W.; Ruoff, R. The chemistry of graphene oxide. Chem. Soc. Rev. 2010, 39, 228-240. [CrossRef] [PubMed]

13. Najjar, A.; Sabri, S.; Al-Gaashani, R.; Kochkodan, V.; Atieh, M.A. Enhanced fouling resistance and antibacterial properties of novel graphene oxide-Arabic gum polyethersulfone membranes. Appl. Sci. 2019, 9, 513. [CrossRef]

14. Gonzalez, J.S.; Ludueña, L.N.; Ponce, A.; Alvarez, V.A. Poly (vinyl alcohol)/cellulose nanowhiskers nanocomposite hydrogels for potential wound dressings. Mater. Sci. Eng. C 2014, 34, 54-61. [CrossRef] [PubMed]

15. Faghihi, S.; Gheysour, M.; Karimi, A.; Salarian, R. Fabrication and mechanical characterization of graphene oxide-reinforced poly (acrylic acid)/gelatin composite hydrogels. J. Appl. Phys. 2014, 115, 083513. [CrossRef] 
16. Hummers, W.S.; Offeman, R.E. Preparation of graphitic oxide. J. Am. Chem. Soc. 1958, 80, 1339. [CrossRef]

17. Chen, L.; Du, Y.; Zeng, X. Relationships between the molecular structure and moisture-absorption and moisture-retention abilities of carboxymethyl chitosan: II. Effect of degree of deacetylation and carboxymethylation. Carbohydr. Res. 2003, 338, 333-340. [CrossRef]

18. Cheng, Y.-W.; Wu, C.-H.; Chen, W.-T.; Liu, T.-Y.; Jeng, R.-J. Manipulated interparticle gaps of silver nanoparticles by dendron-exfoliated reduced graphene oxide nanohybrids for SERS detection. Appl. Surf. Sci. 2019, 469, 887-895. [CrossRef]

19. Mevold, A.H.H.; Hsu, W.W.; Hardiansyah, A.; Huang, L.Y.; Yang, M.C.; Liu, T.Y.; Chan, T.Y.; Wang, K.S.; $\mathrm{Su}$, Y.A.; Jeng, R.J.; et al. Fabrication of Gold Nanoparticles/Graphene-PDDA Nanohybrids for Biodetection by SERS Nanotechnology. Nanoscale Res. Lett. 2015, 10, 397. [CrossRef]

20. Juang, R.-S.; Wang, K.-S.; Cheng, Y.-W.; Fu, C.-C.; Chen, W.-T.; Liu, C.-M.; Chien, C.-C.; Jeng, R.-J.; Chen, C.-C.; Liu, T.-Y. Floating SERS substrates of silver nanoparticles-graphene based nanosheets for rapid detection of biomolecules and clinical uremic toxins. Colloids Surf. A 2019, 576, 36-42. [CrossRef]

21. Liu, C.-C.; Liu, T.-Y.; Wang, K.-S.; Tsou, H.-M.; Wang, S.-H.; Chen, J.-S. The polar solvent effect of transparent conductive films composed of graphene/PEDOT: PSS nanohybrids. Surf. Coat. Technol. 2016, 303, $244-249$. [CrossRef]

22. Stankovich, S.; Dikin, D.A.; Piner, R.D.; Kohlhaas, K.A.; Kleinhammes, A.; Jia, Y.; Wu, Y.; Nguyen, S.B.T.; Ruoff, R.S. Synthesis of graphene-based nanosheets via chemical reduction of exfoliated graphite oxide. Carbon 2007, 45, 1558-1565. [CrossRef]

23. Stankovich, S.; Piner, R.; Nguyen, S.; Ruoff, R. Synthesis and exfoliation of isocyanate-treated graphene oxide nanoplatelets. Carbon 2006, 44, 3342-3347. [CrossRef]

24. Marchessault, R.H.; Morehead, F.F.; Walter, N.M. Liquid Crystal Systems from Fibrillar Polysaccharides. Nature 1959, 184, 632-633. [CrossRef]

(C) 2019 by the authors. Licensee MDPI, Basel, Switzerland. This article is an open access article distributed under the terms and conditions of the Creative Commons Attribution (CC BY) license (http://creativecommons.org/licenses/by/4.0/). 